\title{
KREATYWNE ZARZA¿DZANIE WŁASNYM ŻYCIEM - PRODUKTYWNE GOSPODAROWANIE OSOBISTYMI ZASOBAMI W ŻYCIU PRYWATNYM I ZAWODOWYM
}

\section{WSTĘP}

Wszyscy codziennie stawiamy sobie określone zadania, cele do zrealizowania, radzimy sobie z ogromem obowiązków, wyzwań, jakie stawia każdy dzień, lecz zdarza się, że to obowiązki zarządzają naszym życiem, a nie my ustalamy ich hierarchię. Mamy przeświadczenie, że powinniśmy być lepiej zorganizowani, odnosić więcej sukcesów, spędzać więcej czasu z bliskimi. Jest to niezmiernie trudne wyzwanie, jak dokonywać wyborów i ustanawiać priorytety.

Celem artykułu jest zwrócenie uwagi na tematy dotyczące świadomego zarządzania swoim czasem, życiem zawodowym oraz prywatnym. Jest to obecnie bardzo ważna umiejętność, która uczy, jak planowanie zadań w pracy pozwala zwiększyć swoją efektywność osobistą i jak dzięki temu przyczynia się to do wzrostu wydajności naszej pracy. Odnalezienie wewnętrznego kompasu, który będzie prowadził przez życie, aby pośród różnych wyzwań związanych z codzienną pracą czy też życiem prywatnym pozostać w zgodzie ze sobą.

Każda osoba jest w stanie przywołać w swej pamięci osoby z bliskiego bądź dalszego środowiska, które dokonały w swoim własnym życiu wielu inspirujących, ciekawych zadań, a także takie, którym przeciwnie - nic się nie udaje w życiu i ciągle są niezadowolone z własnych dokonań. W dużym stopniu gospodarowanie własnym życiem zależy od poczucia własnej wartości. Przez całe nasze życie każdy pracuje nad

* Doktorantka, Katedra Socjologii Stosowanej i Pracy Socjalnej, Wydział Ekonomiczno-Socjologiczny, Uniwersytet Łódzki. 
poczuciem własnej wartości. Od naszego wkładu, wysiłku i motywacji zależeć będzie jej poziom. Kiedy wyznaczamy sobie cele życiowe zarówno prywatne, jak i te zawodowe, jednocześnie wyznaczamy sobie jakiś szczyt, który jest naszym maksymalnym punktem do osiągnięcia. „Umiejętność nawiązania pełniejszego kontaktu ze sobą poprzez wzrost świadomości siebie może być pomocne w nawiązaniu kontaktu z zewnętrznym światem, w dokonywaniu życiowych wyborów i przekształcaniu swego otoczenia"1.

Człowiek wyposażony jest w odpowiednie narzędzia, które pozwalają jemu walczyć o poczucie własnej godności, wartości, a przede wszystkim prowadzą do akceptacji samego siebie. Osoba nieakceptująca siebie nie będzie potrafiła przejąć kontroli nad budowaniem swojej samooceny, nabrać dystansu do siebie i otoczenia. To właśnie „akceptacja siebie oznacza generalnie pozytywny stosunek do całej osoby i gotowość do świadomego kontaktu z tym wszystkim, co istnieje i co pojawia się we własnych uczuciach, pragnieniach, myślach i czynach. Akceptacja siebie nie wyklucza możliwości dostrzegania własnych błędów i wad. Ułatwia natomiast zobaczenie ich prawdziwych rozmiarów i kształtów"2.

\section{POSZUKIWANIE WŁASNEGO CELU - CZŁOWIEK JAKO AUTOR WŁASNEGO ŻYCIA}

Podejmując się realizacji jakiegoś celu, skupiamy się często wyłącznie na osiągnięciu samego celu, a pomijamy całą drogę, której trasę wyznaczamy my sami. Nie potrafimy też doceniać samych siebie za „pozytywne przejście” pewnych etapów tej drogi małymi krokami do dużego celu. A zdarza się, że myślimy i robimy odwrotnie chcemy od razu być na szczycie, omijając po drodze, te etapy i to, co nas najbardziej podczas osiągania danego celu może cieszyć. Czy po osiągnięciu celu, kiedy jest on już w naszych rękach, nie zaczyna nam czegoś brakować? Doświadczenie pokazuje, że często stawiamy sobie zbyt duże wymagania i zbyt szybko chcemy dojść do celu, co powoduje, że czujemy się szybko zmęczeni, wypaleni i często po osiągnięciu celu nie odczuwamy satysfakcji. Gdy spotykamy na niej przeszkody szukamy ich genezy nie we własnych decyzjach, a obarczamy nimi los, drugiego człowieka, nieadekwatne warunki panujące $w$ danym czasie. Nie uświadamiamy sobie, że to my decydujemy w którą stronę idziemy, i jak idziemy, jaki mamy pomysł/sposób na osiągnięcie naszych celów. To nasz wewnętrzny kompas podpowiada nam gdzie iść. Obieranie celu związane jest z pracą nad sobą, dokładnym przyglądaniem się własnym przekonaniom, a także, co najważniejsze, samodzielnemu decydowaniu, kto i co może mieć na nas wpływ. „Świadomość jest jak reflektor oświetlający różne obszary wewnętrznej

1 J. Mellibruda, Poszukiwanie siebie, Instytut Psychologii Zdrowia, Polskie Towarzystwo Psychologiczne, Warszawa 2001, s. 21.

2 Ibidem, s. 22. 
i zewnętrznej rzeczywistości. W tej rzeczywistości dokonuje się nieustanne określanie kształtu własnej osoby - poszukiwanie samego siebie, i od właściwości tej rozjaśniającej drogę «latarni» zależy w znacznej mierze to, gdzie i jak daleko zajdziemy”3.

\section{NAJWAŻNIEJSZE ŻYCIE WEWNĘTRZNE}

Poszukiwanie sensu ludzkich dążeń, zagłębianie się w swoje życie wewnętrzne związane jest z poczuciem satysfakcji z podejmowanych wyzwań i ocena ich rezultatów oraz od tego, w jaki sposób interpretujemy siebie i swoje wybory. Wśród powodów/barier, dla których rezygnujemy na samym starcie z podejmowania się określonych wyzwań, zadań nie podejmując nawet najmniejszego wysiłku, małego kroku w kierunku realizacji własnych marzeń i celów są przede wszystkim brak wiary w swoje możliwości i niska samoocena.

„Człowiek jest osobą «personą», bo sam «stwarza siebie» poprzez czyny (własne działania). Niezależnie od wszelkich skutków zewnętrznych skutkiem wewnętrznym jest budowanie siebie - jako sprawczego «Ja», czego wyrazem będzie między innymi charakter danej osoby... Wybór celu działalności człowieka dokonuje się pod wpływem dążeń woli. Nasze osobiste cele związane są z relacjami autotelicznymi, tymi które są dla nas osobiście ważne"4. Warto zatem przyglądać się własnym przekonaniom i własnemu wnętrzu, bo to one nadają rzeczywistości nasz indywidulany, subiektywny kształt. To one determinują samopoczucie i zachowanie. „Samorealizacja nie może być zadaniem wykonywanym na zlecenie pochodzące z zewnątrz. Jej sens polega przede wszystkim na tym, że człowiek przy całej świadomości zewnętrznych uwarunkowań, w których przebiega jego życie ma jednak poczucie, że jest autorem tego życia i że jest za nie odpowiedzialny. Nadaje to sens i znaczenie własnemu życiu. Dzięki poszukiwaniu samego siebie otwieramy się na innych ludzi i to właśnie od nich otrzymujemy rezultaty tych oczekiwań, poprzez kontakt z drugim człowiekiem ${ }^{5}$. Nie może proces ten odbywać się w samotności, w izolacji od świata zewnętrznego, gdyż nie da on nam żadnej informacji zwrotnej o naszym postępowaniu, postrzeganiu, odczuwaniu otaczającego nas świata.

\section{KREATYWNE ZARZĄDZANIE SOBA}

Aby kreatywnie zarządzać sobą, należy zatrzymać się chwilę i zobaczyć jak wygląda nasz indywidualny plan dnia, tygodnia, miesiąca czy roku. Koncentracja na analizie naszego czasu, ilości jego poświęcenia na określone zadania pozwoli nam

3 Ibidem, s. 32.

4 H. Jarosiewicz, Psychologia dążeń i skłonności zawodowych, Wydawnictwo Uniwersytetu Wrocławskiego, Wrocław 2012, s. 169.

5 J. Mellibruda, Poszukiwanie..., s. 41. 
zweryfikować ile z tego czasu przeznaczamy na pracę, na życie prywatne, na czas wolny, czy też po prostu na najzwyklejsze zadania, czy też na lenistwo. Myślą przewodnią kreatywnego zarządzania czasem jest przede wszystkim idea świadomego sterowania własnym życiem - szybciej się rozwijać, nie dać się sterować innym osobom, czy to w pracy, czy w życiu zawodowym. W zarządzaniu czasem koncentrujemy się na dokonaniu przemiany własnej, czasami chaotycznej pracy w planowanie, systematyczne wykonywanie zadań, które ukierunkowane są na osiągnięcie naszego celu. „Zarządzanie czasem jest konsekwentnym i zorientowanym na cel stosowaniem w praktyce sprawdzonych technik pracy w taki sposób, że kierowanie samym sobą i swoim otoczeniem odbywa się bez trudu, a otrzymany do dyspozycji czas jest wykorzystywany sensownie i optymalnie" ${ }^{6}$. Kreatywność odnosić się będzie w tym artykule do postrzegania siebie jako człowieka otwartego na zmiany, chcącego tych zmian i szukającego nowych wyzwań, pomysłowego, a także twórczego w odkrywaniu otaczającego go świata i poszukującego w swoim aktywnym działaniu oryginalnych sposobów na zarządzanie własnym życiem prywatnym i zawodowym, a przede wszystkim zgodnych z własnym postrzeganiem siebie i odczuwaniu satysfakcji z życiowych wyborów. Geneza tego, czy jesteśmy zdolni do przypisywania sobie nagród za osiągnięty sukces, czy też podchodzimy do siebie zbyt pesymistycznie, bez dowartościowywania siebie leży u podstaw naszego dzieciństwa. Inaczej nazwać możemy powyższą sytuację stylem wyjaśniania naszych decyzji. To właśnie w okresie dzieciństwa kształtuje się w człowieku optymizm lub pesymizm, który ma fundamentalne znaczenie dla jego późniejszych poczynań. Jest to rodzaj filtru, przez który postrzegamy nasze niepowodzenia i sukcesy. Styl wyjaśniania wywiera wpływ na życie dorosłego człowieka. Może on powodować depresję jako reakcję na nasze codzienne niepowodzenia albo przeciwnie - może nas uodpornić na prawdziwe tragedie. Styl ten może przeszkodzić nam w osiągnięciu upragnionego celu, ale również może pomóc nam ten cel osiągnąć 7 . Seligman wyodrębnił trzy źródła wpływu na styl wyjaśniania dziecka8:

1. Forma wyjaśnień przyczyn niepowodzeń, jakie dziecko słyszy z ust rodzica, a przede wszystkim matki - jeśli wyjaśnienia matki są optymistyczne, to wyjaśnienia dziecka również będą optymistyczne.

2. Forma uwag krytycznych, których wysłuchuje, kiedy mu się coś nie powiedzie - jeśli uwagi te wskazują na przyczyny stałe i o zasięgu uniwersalnym, to jego obraz własnej osoby stanie się pesymistyczny.

3. Natura strat i urazów, których doświadcza dziecko - jeśli po jakimś czasie wszystko wraca do stanu pierwotnego, to dziecko wyrabia sobie pogląd, że niepo-

6 L. Seiwert, Zarządzanie czasem. Bądź panem własnego czasu, Wydawnictwo Placet, Warszawa 1998, s. 14-15.

7 M. Seligman, Optymizmu można się nauczyć. Jak zmienić swoje myślenie i swoje życie, Wydawnictwo Media Rodzina of Poznań, Poznań 1993, s. 179.

8 Ibidem, s. 205. 
wodzenia można przezwyciężyć, że straty nie są nieodwracalne. Jeśli są jednak one stałe, to nasiona bezradności najprawdopodobniej zapadły głęboko.

„Ślady te mają postać różnych schematów (raz lepszych, a raz gorszych) nawyków i wzorców dotyczących zachowania, myślenia i odczuwania. Mogą być one wartościowe i pomocne w życiu. W pewnym sensie mogą ułatwić i usprawnić działanie i myślenie, skracać wykonywanie czynności, bo mamy już gotowe schematy. Rolą owych śladów jest oferowanie gotowych rozwiązań, reguł, decyzji, przepisów na życie. Nie zawsze jednak tak jest, gdyż są w życiu sprawy i sytuacje, w których to, co gotowe kłóci się z tym, co nowe. Nowe, następne doświadczenia w kolejnych momentach życia to nowe doświadczenia, które mogą zmieniać utrwalone ślady doświadczeń poprzednich, aby same przekształcać się w następne nowe wzory. Jest to dla człowieka nieustający proces uczenia się na podstawie własnych doświadczeń i przeżyć. Zrozumienie i realizowanie procesu uczenia się uzależnione jest od osobistych cech i przeżyć indywidualnych człowieka w danym okresie jego życia9 ${ }^{9}$ Odkrycie i poznanie osobistych, słabych punktów daje szansę na stworzenie odpowiednich strategii w kierunku ich przezwyciężania i usunięcia z naszego życia zawodowego i prywatnego. Takie cechy człowieka jak: wysoka samoocena, optymizm i energia w działaniach ma pozytywny związek z satysfakcją z życia ${ }^{10}$. Badania pokazały wysokie korelacje między zadowoleniem z życia, samooceną i optymizmem, co skłoniło badaczy do sprawdzenia podstaw genetycznych pozytywnej orientacji, jak nazwano tę ogólną właściwość. Wyniki badań pokazały, że orientacja pozytywna jest w dużej mierze dziedziczna ${ }^{11}$. Warto zatem posiadać świadomość tego, w jaki sposób rozmawiać, rozumieć i wspierać dziecko w różnych sytuacjach życiowych. Istotna jest również świadomość rodzica własnego postępowania i odbioru jego zachowania przez dziecko a także wpływu tych wydarzeń na funkcjonowanie dziecka w przyszłości.

\section{NAJPIERW RZECZY NAJWAŻNIEJSZE}

Zdefiniowanie własnej misji jest istotnym warunkiem działania na podstawie paradygmatu ważności. Człowiek tworząc własną misję powinien spróbować odpowiedzieć na kilka pytań koncentrujących się na tym, co jest dla niego najważniejsze, co nadaje sens życiu oraz kim chciałby być i czym chciałby zajmować się w życiu osobistym i zawodowym. Próba odpowiedzi na powyższe pytania oraz ich świadomość jest niezwykle ważna. To nasze przekonania wywierają wpływ na inne sfery naszego życia, a w tym na cele, decyzje, sposób spędzania wolnego czasu, na naszą

\footnotetext{
9 J. Mellibruda, Poszukiwanie..., s. 51.

10 P. Oleś, Psychologia człowieka dorosłego, Wydawnictwo Naukowe PWN, Warszawa
} 2011, s. 292.

11 Ibidem, s. 292. 
aktywność w otaczającej nas rzeczywistości. W celu satysfakcjonującego zarządzania sobą w czasie, warto przyjrzeć się jego alokacji pomiędzy poszczególnymi, ważnymi obszarami życia i zorientowaniu się, któremu z nich osoba oddaje się więcej, a któremu mniej. Zarządzanie sobą w czasie oznacza, że należy nie tylko skupiać się na właściwym robieniu rzeczy, ale przede wszystkim należy skoncentrować się na robieniu właściwych rzeczy. Sposobem walki z nieefektywnym wykorzystaniem czasu jest wyznaczenie sobie celów/priorytetów. Tworząc listę zadań, które można wykonać danego dnia należy koncentrować się na pilności danych zadań, a im ma się więcej rzeczy pilnych, tym zazwyczaj mniej w nich rzeczy ważnych. Organizację codziennych zadań czy też spraw ułatwić może tabela 1 , która pomoże zrozumieć podział na rzeczy ważne i pilne oraz ich wpływ na nasze zarządzanie czasem każdego dnia12.

Tabela 1. Podział rzeczy na ważne i pilne

\begin{tabular}{|c|c|c|}
\hline & PILNE & NIEPILNE \\
\hline WAŻNE & $\begin{array}{l}\quad \text { I } \\
\text { 1. Sprawy naglące } \\
\text { 2. Zadania z określoną datą } \\
\text { do realizacji, zebrania }\end{array}$ & $\begin{array}{l}\text { - } \\
\text { - Planowanie } \\
\text { - Przygotowania } \\
\text { - Sprecyzowanie wartości } \\
\text { - Zapobieganie }\end{array}$ \\
\hline NIEWAŻNE & \begin{tabular}{l}
\multicolumn{1}{c}{ III } \\
- Niektóre spotkania \\
- Niektóre telefony \\
- Najbliższe sprawy naglące \\
- Zwykłe zajęcia
\end{tabular} & $\begin{array}{l}\text { - } \text { IV } \\
\text { - Podzienność } \\
\text { - Przyjemacze czasu } \\
\text { - Prýsi }\end{array}$ \\
\hline
\end{tabular}

ŹRódŁo: Covey S., Roger M., Merrill R., Najpierw rzeczy najważniejsze, Dom Wydawniczy REBIS, Poznań 2013, s. 43

Twórcą tzw. macierzy Eisenhowera jest jeden ze znanych prezydentów Stanów Zjednoczonych - Dwight D. Eisenhower. Jest to jeden z popularnych sposobów rozplanowania własnego czasu/harmonogramu spraw. Macierz ta wizualnie przypomina układ współrzędnych, gdzie rzędną jest ważność danego działania, natomiast odciętą - jego pilność. Najważniejsze w jej realizacji jest odpowiednie rozdzielenie czynności. Często mamy dylemat, czy nasze zadania możemy uznać za mało ważne lub mało pilne? Czy możemy ich nie wykonywać lub zlecić ich realizację komuś innemu? ${ }^{13}$ Od których spraw zacząć, a z których tak naprawdę możemy zrezygnować, które wpływają na nas motywująco, a które to tzw. pożeracze cennego czasu. Na te

12 S. Covey, M. Roger, R. Merrill, Najpierw rzeczy najważniejsze, Dom Wydawniczy REBIS, Poznań 2013, s. 42-43.

13 www.zarzadzanie-czasem.cioswnos.pl/macierz-eisenhowera [dostęp: 27.05.2015]. 
pytania, a także na wiele innych dylematów może odpowiedzieć nam prawidłowo wypełniona macierz Eisenhowera.

Odnosząc się do powyższej tabeli warto poświęcić chwilę i zastanowić się nad realnością poszczególnych ćwiartek macierzy w naszym życiu ${ }^{14}$. Ćwiartka I to ćwiartka koncentrująca się na codzienności, zalicza się do niej praca, interesy, aktywność. Wykorzystujemy w niej własne doświadczenie i wiedzę, by odpowiednio reagować na ludzkie potrzeby i podejmować wyzwania. Warto o tych rzeczach pamiętać i ich nie zaniedbywać. Ćwiartka, która jest jedną z najważniejszych ćwiartek w związku z prawidłowym zarządzaniem naszym czasem, to ćwiartka II, stąd też jest to ćwiartka „wysokiej jakości". Wraz z coraz większą liczbą godzin spędzanych w tej ćwiartce zwiększa się nasza zdolność do działania. Zaniedbywanie przypisanych obowiązków należących do tej ćwiartki, prowadzi do zwiększenia ilości zadań w ćwiartce I, która pochłania nas i nasz cenny czas, powodując stres, „wypalenie”, zmęczenie i brak motywacji do podejmowania kolejnych wyzwań. Ważne jest to, abyśmy wiedzieli, że w ćwiartce II, to my mamy się zmusić do działania, a przede wszystkim to my powinniśmy czuć się zmotywowani do podejmowania aktywności dla zwiększenia własnej satysfakcji z planowania i wykonywania zadań. Ćwiartka II do niczego nas nie zmusza. Jest drogowskazem, jak efektywnie zarządzać samym sobą. Właśnie w niej doskonalimy nasz umysł, rozwijamy nasze zainteresowania, talenty. Nasza zdolność do działania zwiększa się wraz z coraz większą liczbą godzin spędzanych w tej ćwiartce.

Ćwiartka III jest zwana ćwiartką ułudy ${ }^{15}$. Czas spędzany w ćwiartce III, to czas w którym realizujemy tak naprawdę cudze priorytety i zaspokajamy cudze oczekiwania, a nie nasze, co powoduje, że cały czas złudnie myślimy, że jesteśmy w ćwiartce I.

Ćwiartka IV, to obszar pożeraczy czasu ${ }^{16}$. Jest swego rodzaju ucieczką od codzienności, jednak ćwiartka ta nie służy przetrwaniu, lecz często prowadzi do samozniszczenia. Sytuacja taka ma miejsce, kiedy odkładamy ważne sprawy i decyzje na później, a odkładamy je zazwyczaj dlatego, że nie mamy dokładnie sprecyzowanych celów oraz brak w naszym działaniu wyznaczonych priorytetów. Pośpiech, zdenerwowanie i zniecierpliwienie nie wpływają pozytywnie na nasze funkcjonowanie i organizację czasu. Samodyscyplina jest istotna w każdym podejmowanym działaniu. Kontrolowanie własnych decyzji i monitorowanie ich przez nas samych jest jedyną receptą na uzyskanie stabilnego poczucia sprawczości nad własnym życiem prywatnym i zawodowym.

\section{PASJA - ŻYCIOWYM DROGOWSKAZEM}

Informacje zwrotne o nas samych, czy podejmowanych przez nas decyzjach, które otrzymujemy od naszych bliskich, otoczenia, w którym przebywamy na co dzień w niektórych sytuacjach mogą nie mieć dla nas żadnej wartości. Mogą budzić w nas

\footnotetext{
14 S. Covey, M. Roger, R. Merrill, Najpierw rzeczy..., s. 43.

15 Ibidem, s. 44.

16 Ibidem.
} 
lęki, obawy, podcinać skrzydła i utrudniać realizację planów, celów. „Jeśli wizja nas samych jest tylko odbiciem społeczeństwa, nie mamy kontaktu ze swoim wnętrzem, z własną wyjątkowością i zdolnością przyczyniania się do ogólnego dobra. Żyjemy według scenariusza dostarczanego nam przez innych - rodzinę, współpracowników, przyjaciół. Takie scenariusze, dobre czy złe, sprawiają, że trudno nam zrozumieć, kim naprawdę jesteśmy i jacy moglibyśmy być"17. Musimy być świadomi tego, że to tak naprawdę nasza decyzja, w jakim stopniu pozwalamy tym scenariuszom przenikać do naszego prywatnego życia, jaki wywierają na nas wpływ i czy hamują nasze działanie. Możemy ulegać tym scenariuszom, rezygnować z realizacji własnych marzeń i szukać tłumaczeń tych decyzji w braku wsparcia, czy kierowaniem się w życiu złymi radami, w które uwierzyliśmy, ale to wcale nie zwalnia nas z odpowiedzialności za własne postępowanie ${ }^{18}$.

Jeśli przez chwilę przeanalizujemy nasze pragnienia, których doświadczamy każdego dnia, to możemy przekonać się, że zazwyczaj dotyczą one środków służących raczej osiągnięciu pewnego celu niż celom samych w sobie. Dokonując wnikliwej analizy tego pragnienia, zauważamy, że pod danym głównym pragnieniem, znajdują się inne szczegółowe, bardziej podstawowe cele dla nas istotne. Głębsza analiza symptomów pokazuje, że ostatecznie zawsze prowadzi ona do pewnych celów lub potrzeb, których nie możemy już przekroczyć, które są celami samymi w sobie, które nie wymagają już dalszej interpretacji, uzasadnień i dowodów. Analizując powyższą kwestię można stwierdzić, że tak naprawdę to, co daje nam szczęście, satysfakcję, przyjemność to sam fakt i stan dążenia do określonego celu, ta droga do celu, która często składa się z wielu zakrętów, ścieżek „pod górkę”, a czasami „ścieżek z górki”, która mamy wrażenie, że nie ma końca, jest dla nas najszczęśliwszym momentem, którego doświadczamy. Nie do końca liczy się sam sukces czy wynik. Droga, którą podążamy, nasze przeżycia, zdobyta wiedza, poznani ludzie są wartością dodatnią i doświadczanie tego jest najważniejsze. Z tego powinniśmy czerpać radość, z każdego wydarzenia w drodze do mety. Każdy z nas ma szansę na osiągnięcie sukcesu, oczywiście nie zawsze się to udaje. Może nie osiągniemy w stu procentach wyniku, który sobie założyliśmy, ale nawet ta mała część dokonań jest namiastką sukcesu. Warto zatem doświadczać tych momentów, odkrywać swoje pasje i cieszyć się nimi, bo być może gdy osiągniemy już cel nie będziemy potrafili cieszyć się nim na tyle na ile byśmy chcieli. Sukces, to swego rodzaju zwieńczenie tego, co robimy od jakiegoś czasu i co powinno sprawiać nam przyjemność. Warto zatem wyciągnąć z niego wnioski, tak aby był on dla nas drogowskazem na przyszłość. Nie do końca liczy się sam sukces czy wynik. Pasja jest tym, co daje nam siłę wewnętrzną do działania. Jest sama w sobie energią, siłą motywującą. To ona precyzuje cele, wyznacza kierunek i daje również siłę, by w swoich działaniach wykraczać poza swoje zdolności i zasoby. Pozwala pokonać strach, zwątpienie, niepewność i wiele innych barier powstrzymu-

17 S. Covey, M. Roger, R. Merrill, Najpierw rzeczy..., s. 118-119.

18 D. Lebda, Skąd brać siłę do działania?, „Coaching”, Vol. 1, No. 28, 2015. 
jących nas od dążenia naprzód ${ }^{19}$. Pasja daje nam pewność siebie, siłę do tego, aby przeciwstawić się innym i nie pozwolić, aby to inni decydowali o naszym życiu.

Największym źródłem satysfakcji może być przekraczanie własnych granic, „wychodzenie poza istniejący układ" - charakterystyczna dla człowieka transgresja ${ }^{20}$. Ekscytacja wynikająca z eksploracji nieznanego, ożywcza aktywność i zaangażowanie w zupełnie nowe działania, pasje, przekraczanie ograniczeń i poznawanie granic własnych możliwości, pokonywanie cierpienia, często również dają nam wiele satysfakcji cele altruistyczne - poświęcanie siebie (swojego czasu) na rzecz dobra drugiego człowieka, to wszystko nadaje sens działaniu. Elementy te mogą dawać satysfakcję wyższego rzędu - przeświadczenie o sensie istnienia ${ }^{21}$. Pomyślna interakcja dwóch procesów adaptacyjnych wpływa pozytywnie na zwiększanie poziomu zadowolenia z życia. Pierwszym istotnym procesem jest aktywność służąca uzgodnieniu kierunku osobistego rozwoju z celami osobistymi lub tematem życia (asymilacja), drugi proces polega na dostosowaniu celów i ambicji do warunków, w jakich miałyby być realizowane oraz do osobistych możliwości i dostępnych zasobów środowiskowych (akomodacja). Dynamika procesów asymilacji i akomodacji oraz ich względna równowaga jest zależna od stopnia kontroli nad celami i od oceny ich ważności²2.

Kennon Sheldon proponuje model optymalnego ludzkiego istnienia. Słowo „optymalne" odnosi się do pomyślnych i skutecznych sposobów funkcjonowania w takich warunkach, w jakich przychodzi jednostce żyć lub jakie wybiera. Nie chodzi tutaj o nieosiągalny ideał doskonałości. Określenie „ludzkie” koncentruje się na takich właściwościach natury ludzkiej, jak potrzeba zrozumienia i przewidywanie, czyli właściwości poprzedzające decyzję o działaniu. Ostatnie słowo „istnienie” odnosi się do dynamicznego aspektu życia jak: rozwój, wzrost, intencjonalne odniesienie do świata, czy też realizacja dążeń23.

Sheldon wyodrębnia pięć ogólnych zasad optymalnego istnienia człowieka²4, które są podsumowaniem artykułu i swego rodzaju drogowskazem do wypełniania kreatywnie własnego życia tym, co sami nazywamy „szczęściem” i zarządzania osobistymi zasobami w optymalny dla każdego z nas indywidualny sposób.

1. Staraj się służyć czemuś poza sobą, na przykład celom społecznym i kulturowym.

2. Poszukaj zrównoważonego zaspokojenia potrzeb.

3. Bądź gotów do pracy nad sobą (lub próbuj modyfikować) problemowe aspekty Ciebie lub Twojego świata.

4. Bierz odpowiedzialność za swoje cele i wybory.

5. Słuchaj swego organizmu i naturalnego procesu wartościowania i bądź gotów na zmianę swych celów, gdy jest to konieczne.

19 S. Covey, M. Roger, R. Merrill, Najpierw rzeczy..., s. 119.

20 Por. P. Oleś, Psychologia człowieka...

21 Ibidem, s. 300.

22 Ibidem, s. 294.

23 Ibidem, s. 297.

24 Ibidem, s. 199. 


\section{PODSUMOWANIE}

Wszystkie wartości, a w szczególności: poczucie wolności, sprawczość, autonomia, odpowiedzialność, a także dojrzałość i mądrość nie gwarantują wysokiej satysfakcji z życia, w którym jest miejsce na los, przypadek, a także na oddziaływania wydarzeń historycznych. Mogą one przyczyniać się do korzystnego bilansu i oceny życia jako bezcenna wartość ${ }^{25}$. Należy więc starać się zarządzać własnym życiem w najbardziej optymalny dla nas sposób, który da nam przede wszystkim własną wewnętrzną satysfakcję i siłę do podejmowani różnych wyzwań w przyszłości. W życiu zdarzają się sytuacje, które są wielkim sprawdzianem, wymagają skorzystania z posiadanych talentów i cech w nowy, kreatywny i skuteczny sposób, trzeba zatem stawiać czoło pewnym wyzwaniom, zobaczyć świat zupełnie inaczej, inaczej spojrzeć na stosunki z ludźmi, inny wyda się wtedy czas. Dobrze jest stawiać sobie cele i pamiętać, że liczy się droga - nie tylko cel. Cel można osiągnąć na dobrej drodze, w tym tkwi sedno satysfakcji i zadowolenia z osiągniętego celu i w tym sensie droga jest najważniejsza.

Uświadomienie sobie tego, jak dzielić sprawy na naprawdę ważne i takie, które można pominąć oraz podtrzymywanie dobrych nawyków, tak by mieć kontrolę nad własnym życiem i być z niego zadowolonym, to podstawa do produktywnego i harmonijnego gospodarowania własnymi zasobami w życiu zawodowym, jak i osobistym.

\section{BIBLIOGRAFIA}

Babiel J., Motywacja - droga do sukcesu, Wydawnictwo Benefit IP, Warszawa 2013.

Covey S., Roger M., Merrill R., Najpierw rzeczy najważniejsze, Dom Wydawniczy REBIS, Poznań 2013.

Jarosiewicz H., Psychologia dążeń i skłonności zawodowych, Wydawnictwo Uniwersytetu Wrocławskiego, Wrocław 2012.

Kottler J., Opór w psychoterapii. Jak pracować z trudnym klientem?, Gdańskie Wydawnictwo

Psychologiczne, Gdańsk 2003.

Lebda D., Skąd brać siłę do działania?, „Coaching”, Vol. 1, No. 28, 2015.

Maslow A., Motywacja i osobowość, Wydawnictwo Naukowe PWN, Warszawa 2006.

Mellibruda J., Poszukiwanie siebie, Instytut Psychologii Zdrowia, Polskie Towarzystwo Psychologiczne, Warszawa 2001.

Oleś P., Psychologia człowieka dorosłego, Wydawnictwo Naukowe PWN, Warszawa 2011.

Seiwert L., Zarządzanie czasem. Bądź panem własnego czasu, Wydawnictwo Placet, Warszawa 1998.

Seligman M., Optymizmu można się nauczyć. Jak zmienić swoje myślenie i swoje życie, Wydawnictwo Media Rodzina of Poznań, Poznań,1993.

Szmidt K., Modrzejewska-Świgulska (red.), Zasoby twórcze człowieka, Wydawnictwo Uniwersytetu Łódzkiego, Łódź 2013.

\section{Źródła internetowe}

www.zarzadzanie-czasem.cioswnos.pl/macierz-eisenhowera

25 Ibidem, s. 300. 